
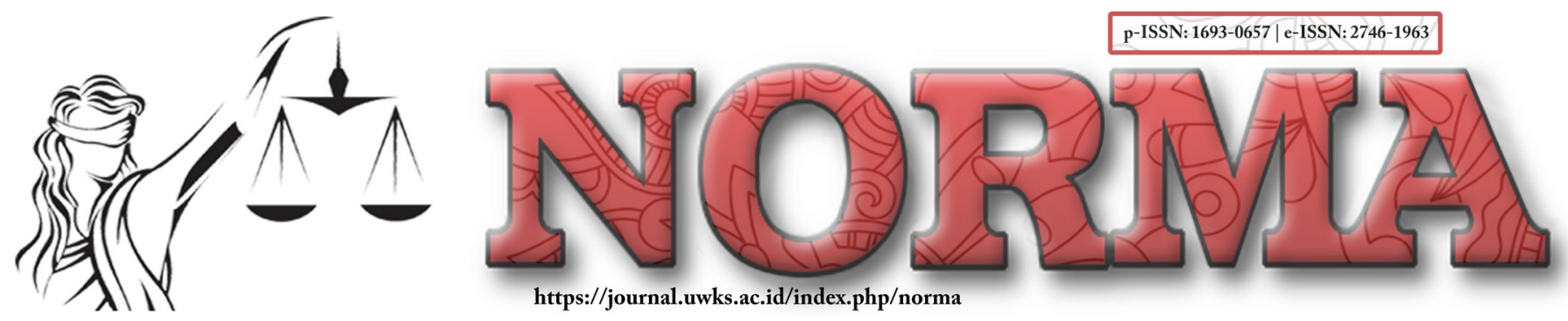

\title{
Characteristic of Notary Deeds for Transactions Through Electronic Media
}

\author{
Fani Martiawan Kumara Putra \\ Faculty of Law Universitas Wijaya Kusuma Surabaya \\ e-Mail: fanimartiawan@gmail.com
}

\begin{abstract}
:
These technological advances have caused enormous changes to business people who will indirectly use modern technological advances. This development will undoubtedly bring changes to the Notary duties and authorities' implementation as public official authorized to do authentic deeds. A new dynamic of society changes due to globalization and developments in information technology that require Notary services in carrying out existing legal actions, facilitated by current information technology. However, Notaries are still hampered by the absence of legal instruments that protect and regulate Notaries in carrying out these actions. This is a challenge for the Notary profession in responding to globalization in information technology, meaning that the Notary's duties as public officials develop along with the times. This research is normative research with a statutory approach. The results obtained from this research are that the Notary Public must involve a third party called the Certification Authority, to secure and legitimize documents into electronic transactions. The Notary deed to be used remains an authentic deed and has perfect evidentiary power. Still, suppose the process does not involve the party. In that case, the Notary deed is classified as an underhand deed, and has the power of proof as to the deed underhand, even though it is made and signed either directly or digitally by the Notary.
\end{abstract}

Keywords: Notary; Electronic Transaction; Notary Deeds

Article's History:

Received:

19 November, 2020;

Received in revised form:

13 December, 2020;

Accepted:

14 January, 2021;

Published:

14 January, 2021.

DOI:

10.30742/nlj.v17i3.1091

\section{INTRODUCTION}

In this era of globalisation, technology is overgrowing. It seems as if there are no more boundaries between space and time that can separate someone who can separate someone from being in another place. This development is also in line with the development of a traditional society into a modern one, and then automatically, this development demands that the community move towards globalisation.

These technological advances have caused enormous changes to business people who will indirectly use these modern technological advances. In Indonesia, there is already Law no. 11 of 2008 concerning Electronic Information and Transactions (from now on referred to as the ITE Law), as a response to the changing dynamics of society or business actors with globalisation field of information technology. However, some 
business people do not know that business activities carried out through online media should require a legal umbrella that protects these activities. To be safe, a transaction in online media should require a form of an agreement called a Notary deed.

The Notary position's arrangement is contained in Law No. 2 of 2014 concerning Amendments to Law No. 30 of 2004 concerning the Position of Notary (from now on referred to as the New UUJN). Based on the Authority of the Notary as regulated in Article 15 UUJN and the evidentiary power of the Notary deed, there are 2 (two) things that can be understood, namely:

1. Notary in his duties or positions formulate the wishes/actions of the parties into an authentic deed with due observance of the applicable legal rules;

2. The Notary Deed as an authentic deed has perfect evidentiary power, so it does not need to be proven or added with other evidence.

The Special Authority of Notaries can be assessed in article 15 of the UUJN which regulates the particular Authority of Notaries to carry out specific legal actions such as: 1. Ratify the signature and determine the date certainty of the letter under the signature by registering it in a particular book;

2. To record letters underhand by registering in a particular book;

3. Make original copies of the letters under the hands of similar copies containing the rules of the description as written and described in the letter concerned;

4. To validate the compatibility between the photocopy and the original letter;

5. Provide legal education in connection with the deed maker;

6. Doing deeds relating to land, or;

7. Prepare a deed of auction minutes

In connection with these developments, the presence of information technology, of course through the internet media, gave birth to a legal phenomenon in the form of electronic contracts, namely agreements of the parties made through electronic media, as well as electronic contracts in the form of legal actions carried out using computers or computer networks and media. Other electronics. With this information technology, business transactions are no longer carried out in a face-to-face manner between parties, such as sellers and buyers. Still, they can be carried out through information technology developments where the parties do not meet directly or physically.

This development will undoubtedly bring changes to the Notary duties and authorities' implementation as public official authorised to do authentic deeds. In connection with other contracts/agreements or deeds that are not related to land, they shift from the conventional system through face-to-face with the parties, shifting to Notary based on electronic systems in cyberspace.

Notaries, as public officials who carry out part of the State's duties in the civil sector, have significantly benefited from information technology development. The implementation of information technology by Notaries includes online registration 
of companies (legal entities) through SABH Director-General AHU Depkumham RI, email for sending data from clients, and other matters related to the use of information technology. ${ }^{1}$

The ITE Law contains arrangements for electronic transactions with the support of Electronic Certificates, Electronic Signatures, and Electronic Systems. With Electronic Certificates and Electronic Signatures, the parties transacting with each other can be authenticated as the signatory. The status of the signed documents/electronic information is known. The development of business and commerce has now entered the realm of electronic transactions, not conventionally. Technological advances have made it possible to hold electronic transactions using media and technological devices, including the internet. ${ }^{2}$

Electronic transactions are a new form in the world of commerce, which is a promising business alternative because it provides a lot of convenience for both parties, both from the seller and from the buyer, to carry out trade transactions effectively and quickly where the buyer accesses the website of the company that advertises its products and agrees to the terms and provisions from the seller through internet media.

Business actors offering products through electronic systems must provide complete and correct information regarding the terms of the contract, the manufacturer, and the products being offered. The parties which carry out electronic transactions certainly want security and legal certainty with the agreement they made.

The ITE Law has also accommodated electronic documents as valid evidence, but this does not apply to all things because it limits their use. This can be seen in Article 5 paragraph (4), which determines that the provisions regarding electronic information and/or electronic documents as referred to in paragraph (1) do not apply to:

1. A letter which according to the Law must be in writing

2. According to the Law, securities and documents must be in the form of a notary deed or a deed drawn up by the deed-making official.

With this article's existence, the Notary as a public official who has the Authority to legitimize a specific title has no electronic transactions opportunity.

Until now, there has been no legal instrument regulating the legalization of electronic deeds or contracts by notaries because the signing and ratification of electronic signatures require special rules, and the role of a Notary in this case in Indonesia is carried out by a CA (Certification Authority) institution or an electronic certification organization, namely an institution that certifies the digital signature as an independent third party that has the Authority to issue a digital certificate containing the identity of the user.

\footnotetext{
${ }^{1}$ Habib Adjie. (2004). Penggerogotan Wewenang Notaris Sebagai Pejabat Umum. Jakarta: Renvoi, p.

${ }^{2}$ Ibid.
} 32. 
Starting from some of the phenomena above, it can be seen that there are new dynamics of changes in society due to globalization and developments in information technology that require the services of notaries in carrying out existing legal actions, with the current information technology facilitation. However, notaries are still hampered because there are no legal instruments that protect and arrange the Notary in doing the act. This is a challenge for the Notary profession in responding to globalization in the world of information technology, meaning that the Notary's duties as public officials develop along with the times. Therefore, it is necessary to discuss the extent to which the Notary may play a role in issuing certificates.

\section{PROBLEM FORMULATION}

Based on the brief description in the background mentioned above, the problem in this study is the Characteristics of Notary Deeds for Transactions Through Electronic Media

\section{RESEARCH METHOD}

This research is a normative study, which means that this research examines the legislation's side, not reading social symptoms due to existing legislation. This research's approach method is a statutory approach (statue approach) and conceptual approach. This approach is used because the discussion in this study will refer to the Law and the concept related to the issue.

\section{DISCUSSION}

A notary is a Public Official who has the Authority to make Authentic Deeds regarding all actions, agreements, and regulations required by laws and regulations and/or that those with interest want to be stated in an authentic deed, guarantees the certainty of the date of making the deed, keeps the deed, provides Grosse, copies, and excerpts of deeds, all of which as long as the making of the deeds is not assigned or excluded to other officials or other persons stipulated by Law.

Notaries act as public servants because the government appoints them to serve the community's needs for valid legal documents. In carrying out daily duties, notaries are officials who act passively because they wait for the public to come to them to be served. The duties and powers of a notary, among others:

1. Make a deed of establishment/articles of association: business entities, social agencies (foundations), cooperatives, etc.;

2. Making a will deed;

3. Doing a Fiduciary deed;

4. Legalizing (validating the suitability of photocopies of letters);

5. Preparing and registering / marking/warning the letters underhand, etc.; 
6. Preparing and legalizing documents underhand, such as a power of attorney, the statement letter, letter of approval;

7. Doing agreement deeds.

Electronic commerce or e-commerce (English: Electronic commerce, also e-commerce) is the distribution, buying, selling, marketing of goods and services through electronic systems such as the internet or television, www, or other computer networks. E-commerce can involve electronic fund transfers, electronic data exchange, automated inventory management systems, and automated data collection systems. Based on Article 1 paragraph 2 of the ITE Law, the meaning of Electronic Transactions is a legal act that is carried out using computers, computer networks, and/or other electronic media. In the industrial era followed by the advancement of trade, both at the national, regional, and international levels, it has been followed by trade laws regulating trade transactions at the national and global levels. Trade law regulates how a trade agreement is legally made so that it is obeyed by the parties making it.

\section{Notary Authority}

Authority (or often written as Authority) is a legal action regulated and given a position based on the prevailing laws and regulations. Thus, every Authority has its limits, as stated in the statutory regulations governing it. Likewise, the Authority of a notary is limited, as in the laws and regulations governing the position, namely by Law No.2 of 2014 concerning amendments to Law No. 30 of 2004 concerning the Position of Notary. ${ }^{3}$

Notary as a position (not a professional or professional position) and any position in this country have its own Authority. Every Authority must have a legal basis, so that the Authority of any official must be apparent and strictly limited in the laws and regulations governing the official or position.

The source of Authority obtained from a position can be traced, namely by Attribution, Delegation, or Mandate. Delegation of Authority is the transfer/transfer of existing Authority based on statutory regulations or legal rules. And the mandate is not a transfer or transfer of Authority, but because the competent person is absent. ${ }^{4}$

So that if an official commits an action beyond the Authority as determined and limited by Law, the dressing is an illegal act in that context it can be categorized as action outside of Authority or acting arbitrarily.

${ }^{3}$ Habib Adjie. (2008). Hukum Notaris Indonesia, Tafsir Tematik Terhadap UU No. 30 Tahun 2004 Tentang Jabatan Notaris. Bandung: Rafika Aditama, p. 72.

${ }^{4}$ Ibid. 
Notary as regulated in Article 15 of Law Number 2 of 2014 in conjunction with Law No. 30 of 2004 concerning the Position of Notary Public whose Authority is divided into 3 (three) namely: ${ }^{5}$

1. Notary Public Authority (Article 15 paragraph (1) of the New UUJN);

2. Special Authority of Notary (Article 15 paragraph (2) of the New UUJN);

3. Notary Authorities to be Determined Later (Article 15 paragraph (3) of the New UUJN).

\section{The urgency of Notary Engagement in Electronic Transactions}

The existence of a Notary in legal transactions in Indonesia has been recognized for its role and position. It is respected as appropriate as the State's presence in legal relationship transactions because as a third party trusted by the State through Law to use the stamp of the Garuda State symbol so that the public has full trust in the Notary.

The Notary is an official or legal professional who is sworn to act according to the Law appropriately, so it can be said that the Notary's role is essential to maintain the certainty and legality of legal actions to prevent and avoid any illegal acts. ${ }^{6}$

Qualification and criteria as a Notary are based on high ethics and a level of trust, acting honestly under the applicable Law. Unlike lawyers, notaries are considered to have a role and act neutral because they do not work in clients' interests, but act on the Law. Therefore, for each activity and its act, the Notary can be said to be fully responsible. The quality of the document is categorized as an authentic deed and has executorial power. ${ }^{7}$

The development of business and commerce has now entered the realm of electronic transactions, and it is no longer common to use conventional methods. The current ITE Law contains electronic transaction arrangements with Electronic Certificates, Electronic Signatures, and Electronic Systems support. With Electronic Certificate and Electronic Signature, the parties that transact with each other can be authenticated as to who the signatory is. The status of the signed electronic document/ information is known. Technological advances have made it possible to hold electronic transactions using media and technological devices, including the internet. Electronic transactions are a new form of commerce, a promising business alternative because it provides many conveniences for the parties. ${ }^{8}$

${ }^{5}$ Tan Thong Kie. (2007). Studi Notariat ESerba Serbi Praktek Notaris. Jakarta: PT Ichtiar Baru van hoeve, p. 503.

${ }^{6}$ Edmon Makarim. (2013). Notaris \& Transaksi elekronik. Jakarta: RajaGrafindo, p. 7.

${ }^{7}$ Ibid.

${ }^{8}$ Didik M. Arif Mansur dan Elisatris Gultom. (2009). Cyber Law, Aspek Hukum Teknologi Informasi. Bandung: Refika Aditama, p. 122. 
In general, protection is a need for everyone to get assurance that any transaction that is carried out obtains and requires legal protection for every legal relationship transaction that will be or is being carried out, including what is done electronically.

This legal protection is in the form of recognizing the evidentiary value of electronic information and ensuring the fulfillment of the subjective elements of the conditions of the contractual relationship, which determines the legality of a transaction. This subjective element will be fulfilled if there is clarity about the parties' legal identity and their legal capacity. To ensure this, the existence of a Notary is to prevent possible fraud in electronic transactions.

By involving a notary in electronic transactions, the transacting party can determine the legal certainty in the transaction and law enforcers, making it easier to explain the validity and strength of evidence from digital or electronic evidence. This is because the power of proof of information and electronic transactions often has weak evidentiary value. By involving a notary, the transaction and its parties' position will be more decisive because it can be perceived as an authentic deed. Of course, this will increase public trust and security in electronic transactions. ${ }^{9}$

The opportunity for a Notary to play a role electronically is not seen in the New UUJN. However, the application of this is still very relevant to the provisions of Article 15 paragraph (2) point (a) and paragraph (3) of the New UUJN, which gives the Notary another authority as long as it is appropriate. With laws and regulations. Article 15 paragraph (3) of the New UUJN, confirms that Notaries also have other powers regulated in statutory regulations. Elucidation of Article 15 paragraph (3) of the New UUJN, explains that the other powers referred to are also the Authority to certify transactions carried out electronically. Based on this, this Authority is not very appropriate when referred to as certification, because the intended meaning is actually "strengthening" the electronic transaction so that it can be considered legally valid. One form of electronic strengthening or legalization is in the form of a timestamp or legalizing a transaction at a particular time that is carried out between the parties. Conventional forms of legalization include the legalization of signatures in a document, which is also regulated as one of the notary authorities based on UUJN.

The digital printed signature has been implemented in terms of forming a Limited Liability Company, namely in the Decree of the Minister of Law and Human Rights (KEMENKUMHAM). Suppose a Notary Public implements this. In that case, it can become a problem regarding the strength of proof on a digitally printed signature, even though, as described above, one of the things that stands out from a Notary deed is a strong power of evidence. Therefore, the Notary at least has a reference to a procedure or system that can guarantee the creation, storage, or use of public documents that

${ }^{9}$ Makarim Edmon. (2013). Notaris dan Transaksi Elektronik, Kajian Hukum tentang Cybernotary atau Electronic Notary, Edisi ke-2. Jakarta: Rajawali Pers, p. 64. 
they have created or legalized so that they can be considered authentic, as authentic as written certificates.

The implementation of the legalization of information or documents electronically is stated in Article 16 letter C of the New UUJN, which is obligatory for tappers to attach letters and documents and fingerprints on the Minuta Deed. Thus, the deed's authenticity using an electronic signature can be doubted because there is no fingerprint of the intended person.

\section{Notary Position in Electronic Transactions}

The position and role of a Notary are highly expected to be involved in electronic transactions to give strong legitimacy to ongoing electronic transactions, namely identifying electronic signatures and signers and verifying signed electronic documents/information. The Notary must be assisted and collaborated with a third party as an Electronic Certificate Operator. These third parties are entrusted with the Authority to maintain and secure electronic contracts by providing and auditing Electronic Certifications. The Notary's position is to give legitimacy, while the Electronic Certification Operator guarantees electronic agreements' safety.

The role of a notary in electronic transactions is inseparable from the legal infrastructure's readiness and by what method the parties want the electronic transaction to be carried out. Several alternatives to the role of a notary in electronic commerce are as follows:

1. The parties make an offer (offer) and accept the offer (exception) through electronic media, sign the agreement electronically, and put the agreement in a notary deed conventionally. To make a deed contact the Notary of electronic media;

2. The agreement of the parties is carried out electronically. The Notary affixes an electronic signature on the deed, and then the deed is printed as evidence of an agreement;

3. Preparation of Notary deeds is carried out electronically without being followed by the printing of deeds.

Concerning electronic transactions involving Notaries, the Notary's position in electronic commerce is as follows: ${ }^{10}$

1. Notary position in electronic transactions and Certificate Authority (CA) as a trusted third party in securing and legitimizing electronic transactions. Certificate Authority is the party that issues an Electronic Certificate which contains the identity of the certificate owner, public key, and private key used in electronic transactions to create electronic signatures, authenticate the signer and verify the signed documents;

${ }^{10}$ Habib Adjie. (2008). Hukum Notaris Indonesia, Tafsir Tematik Terhadap UU No. 30 Tahun 2004 tentang Jabatan Notaris. Bandung: Rafika Aditama, p. 73. 
2. The Notary acts to authenticate parties which carry out electronic transactions or authenticate parties who sign documents/electronic information, verify documents/electronic information signed by the parties, safeguard the storage of data in the form of signatures and signed copies, assist CA in Electronic Certificate issuance, in particular, identifies the parties requesting the issuance of Electronic Certificates, and finally becomes an intermediary for electronic transactions where the Recipient sends the electronic documents and signatures to the Notary, then the Notary performs authentication and verification first of the signers and the electronic documents/information that are signed, then forwarded to the Recipient; 3. The Notary checks the signature used, the sender's identity, and the signed electronic documents/information. If this inspection is complete, the Notary can send the checking result information to the sender. If there is no problem, then the Notary sends the electronic document/information to the Recipient. The Receiving Party submits information to the Notary that the document/electronic data has been received. The Notary follows up the notification by sending information/ reports to the sender that the Recipient has received a signed electronic document/ information.

Notaries are expected to play a role in doing electronic deeds. Until now, no law allows for an electronic Notary deed making system because the New UUJN and the ITE Law have not regulated the system.

Doing authentic deeds related to electronic documents in e-commerce can be done in the presence or by a notary public. It must also pay attention to the authenticity requirements so that electronic records and digital signatures in them can be used as valid and perfect evidence. Regarding the authenticity of electronic documents and digital signatures, an institution must be established to carry out a Certification Authority that involves a Notary in it, under the Certification Authority Supervisory Body's supervision. ${ }^{11}$

In this regard, various normative and technical improvements are still needed, by making amendments to the Notary Position Law and the ITE Law relating to the office area of a Notary, namely a Notary having an office area in all provinces where his/her domicile is located - and giving Authority to Notaries in the cyber world as certification authority by observing the basic principles of the validity of authentic deeds. For this reason, if necessary, it is required to establish firmer laws and regulations to support the Notary role in the electronic deed-making system.

Based on the elaboration above, following Article 15 paragraph (1) of the New UUJN concerning the Authority of Notaries, that the Notary is authorized to make authentic deeds regarding all actions, agreements, and stipulations required by the regulations to be stated in authentic deeds, guarantee the certainty of the date of doing

11 Ibid. 
the deed, keep the deed, provide Grosse, a copy and an excerpt of the deed, all of which as long as the deed is done, it is not assigned or excluded to other officials or other people as stipulated by Law.

In connection with a notary involvement in electronic transactions, a notary is needed for doing deeds so that they have perfect evidentiary power, as authentic deeds made by notaries in general. However, the character of electronic transactions only involves interested parties and is carried out digitally, so it requires a digital signature. The presence of a Notary as a party can support the power of perfect proof. If the deed is done by or in the Notary's existence, the electronic transaction is digitally signed to have ideal proof power. ${ }^{12}$

In the practice of transactions via electronic media to obtain perfect evidentiary power as in the form of deeds made by and before a Notary Public, improving the power of proof of Notary deeds made digitally requires the involvement of a third party in the form of a trusted certificate authority (CA). In securing and legitimizing documents into electronic transactions.

The institution also issues Electronic Certificates containing the owner's identity, public keys, and private keys used in electronic transactions to create electronic signatures, authenticate the signer, and verify the signed documents. The Notary acts to authenticate the parties conducting electronic transactions or authentication of parties signing documents/electronic information, verifying documents/electronic information signed by the parties, securing information storage in the form of signatures and signed documents. ${ }^{13}$

\section{Strength of Proof of Notary Deed in Electronic Transactions}

In the development of electronic means in various transactions, besides providing positive benefits, namely the ease of transactions, it also offers enormous benefits for document storage due to business activities carried out. However, with the rapid development of electronic means and the increasing number of electronic advice users, there are also weaknesses or weaknesses when faced with evidence problems before the court. ${ }^{14}$ In this case, the legal position of proof, as usual, will be in a dilemma. On the one hand, so that the Law can always acknowledge the times and technology, it is necessary to have legal recognition of various digital technology developments to function as court evidence. On the other hand, there is a tendency to manipulate digital evidence by irresponsible parties.

\footnotetext{
${ }^{12}$ Habib Adjie, op.cit., p. 74.

${ }^{13}$ Emma Nurita. (2012). Cyber Notary, Pemahaman Awal Dalam Konsep Pemikiran. Bandung: Refika Aditama, p. 25.

${ }^{14}$ Ibid.
} 
The provisions referred to in Article 5 paragraph (4) letter b of the ITE Law: "Provisions regarding Electronic Information and/or Electronic Documents as referred to in paragraph (1) do not apply to:

1. A letter which according to the Law must be in writing; and

2. According to the Law, letters and documents must be made in the form of notary deeds or deeds drawn up by the deed-making official.

The ITE Law provides a position on electronic documents with digital signatures as evidence because electronic data has not been accommodated in the Evidence Law and Procedural Law system in Indonesia. This is an extension of evidence-based on the Law of Evidence in Indonesia, which only recognizes 5 (five) types of evidence. BW determines that written evidence consists of personal data and data to run the company. Electronic information as evidence in civil evidence originates from the idea that the essence of e-commerce lies in electronic information and electronic signatures as the key to securing it.

The laws related to letters and documents as referred to in Article 5 paragraph (4) of the ITE Law include BW, Law Number 25 of 1992 concerning Cooperatives (Cooperative Law), Law Number 16 of 1985 regarding Flats (RS Law), Law Number 40 of 2007 regarding Limited Liability Companies (PT Law), Law Number 4 of 1996 concerning Land Mortgage Rights and Land-related Objects (HT Law), Law Number 42 1999 concerning Fiduciary Guarantee (Fiduciary Law), Law Number 16 the Year 2001 as amended by Law Number 28 the Year 2004 concerning Foundations (Foundation Law), and Law Number 30 the Year 2004 concerning Notary Position (JN Law). In addition to the deeds in several of these laws, the ITE Law provisions may apply. ${ }^{15}$

Electronic documents and digital signatures born from e-commerce need to be reviewed concerning authentic deeds. The ITE Law's birth raises questions among notaries whether electronic transactions or electronic documents can be equated with authentic deeds. Apart from paying attention to the requirements for the authenticity of a document, the document authenticity process and electronic information can be obtained in the event of a legal dispute. Legal disputes regarding electronic documents in electronic transactions can be resolved by litigation. This dispute's settlement is subject to civil procedural Law and its proof system, which adopts a positive proof system. The parties in an electronic transaction must prove, while the Judge only shares and charges the party to submit evidence to corroborate the presented arguments or events. This is following the general principle in Article 163 HIR / 283 RBG / 1865 BW.

Based on Article 5 paragraph (4) of the ITE Law, electronic documents cannot be equated with an authentic deed made by or before a notary because the authenticity of notary deeds is based on the Law on Notary Position. Therefore, the power of proof

${ }^{15}$ Habib Adjie. (2008). Hukum Notaris Indonesia, Tafsir Tematik Terhadap UU No. 30 Tahun 2004 tentang Jabatan Notaris. Bandung: Rafika Aditama, p. 38. 
of electronic documents can be equalized with a deed under hand but must meet the basic requirements so that a document has value as an underhand deed. The essential requirement is that the letter or writing is signed; the content described in it is related to legal actions (rechtshandeling) or legal relations (Recht bettrekking), and deliberately made to be used as evidence of the legal action mentioned in it. Besides, electronic documents to function as valid evidence must also meet the ITE Law requirements.

The notary deed and the underhand deed have differences in proof. The proof of an underhand deed is much weaker than an authentic deed, so that if there is a change from an authentic deed to an underhand deed, the parties will suffer the most loss. Underhand deeds made for the parties' benefit in proving to a third party, without an official's help, have evidentiary value as long as the parties acknowledge it and there is no denial from either party. If there is denial, the burden of proof is left to the party who denies it, and the assessment of the rejection of the evidence is submitted to the Judge. This is following the Civil Procedural Law evidentiary system.

It is different from an authentic deed, which has perfection as evidence so that the deed must be seen as it is and does not need to be interpreted differently from what is written in the deed. This means that the power of proof of deeds underhand is not as extensive and as high as the degree of authentic deeds because authentic deeds have physical, formal, and material evidentiary power while deeds underhand do not have physical evidentiary power but are only limited to the strength of formal and material proof with weight, which is much lower than the authentic deed. ${ }^{16}$

Legal recognition of the power of proof of electronic signatures is something that cannot be avoided. The development of technology has been so advanced. The Law, including the Law of proof, should be able to anticipate these developments. Laws are made so that they can reach the future, not always compromise with current conditions. Laws must be futuristic. Electronic signatures are a daily reality in banking activities. What is needed is a legal attachment or footing that recognizes an electronic signature as legally valid evidence. Based on the need for a third party (Certification Authority) when a notary is used to have the power of proof, the power of proof of electronic documents can be the same as an authentic deed, because of electronic information and/or electronic document that has been signed electronically means that the information and/or documents have been verified and authenticated. This is different from BW which only recognizes a signed letter as binding evidence, while a letter without a signature is only preliminary evidence that is not binding. ${ }^{17}$

The legal relationship between a notary, the ITE Law, and the meaning of a signature can be stated in an adage that all electronic transactions with electronic signatures can be considered as deeds. Even the power of proof is the same as an

\footnotetext{
${ }^{16}$ Habi Adjie. (2004). Penggerogotan Wewenang Notaris Sebagai Pejabat Umum. Jakarta: Renvoi, p. 66.

${ }^{17}$ Ibid., p. 70.
} 
authentic deed. This legal relationship has implications for the burden of proof of an electronic signature. This electronic sign can be applied in Indonesia, but not for electronic documents that may be authentic. The authentication of deeds related to the legalization process cannot convert electronic documents as underhand deeds into authentic deeds. If the electronic document or deed is used as written evidence as required by Article $164 \mathrm{HIR}$, the document must fulfill the agreement's terms based on BW. ${ }^{18}$

Based on the description above, it can be concluded that the notary deed used in a sale and purchase transaction through electronic media, primarily buy and sell on a large scale to provide more protection to the parties, turns out that the power of proof is equivalent to a deed underhand, however, if the Notary deed also involves a third party (Certification Authority), the Notary deed can have the power of proof just like an authentic deed. Regarding the process of proof, proof in procedural Law has a juridical meaning, meaning it only applies to parties in litigation or who has obtained rights from them. The purpose of this evidence is to provide certainty to the Judge about the existence of certain events depending on the parties at trial to strengthen the evidence presented. ${ }^{19}$

\section{CLOSING}

\section{Conclusion}

In connection with a notary involvement in electronic transactions, the Notary cannot work independently as usual. Still, the Notary must involve a third party called the Certification Authority, to secure and legitimize documents into electronic transactions so that the Notary deed to be used remains an authentic deed and has perfect evidentiary power. Still, suppose the action does not involve the party. In that case, the Notary deed is classified as an underhand deed, and has the power of proof as an underhand deed, even though it is made and signed either directly or digitally by a Notary Public.

\section{Recommendation}

Notaries cannot act independently because they must be accompanied by a third party (CA). Therefore, at least a new arrangement has been formed, which confirms and makes the position and independence of the Notary well manifested, without the need for third-party intermediaries.

${ }^{18}$ Habib Adjie. (2008). Hukum Notaris Indonesia, Tafsir Tematik Terhadap UU No. 30 Tahun 2004 tentang Jabatan Notaris. Bandung: Rafika Aditama, p. 78.

19 Tan Thong Kie. (2007). Studi Notariat E Serba Serbi Praktek Notaris. Jakarta: PT Ichtiar Baru van hoeve, p. 503. 


\section{REFERENCES}

Burgerlijk Wetboek (BW).

Undang-Undang No. 30 Tahun 2004 tentang Jabatan Notaris.

Undang-Undang No. 2 Tahun 2014 tentang Perubahan Atas Undang-Undang Nomor 30 Tahun 2004 tentang Jabatan Notaris.

Undang-Undang No. 11 Tahun 2008 tentang Informasi dan Transaksi Elektronik.

Didik M. Arif Mansur dan Elisatris Gultom. (2009). Cyber Law, Aspek Hukum Teknologi Informasi, Bandung: Refika Aditama.

Edmon Makarim. (2013). Notaris dan Transaksi Elektronik, Kajian Hukum tentang Cybernotary atau Electronic Notary, Edisi ke-2. Jakarta, Rajawali Pers.

Emma Nurita. (2012). Cyber Notary, Pemahaman Awal Dalam Konsep Pemikiran. Bandung: Refika Aditama.

Habib Adjie. (2004). Penggerogotan Wewenang Notaris Sebagai Pejabat Umum. Jakarta: Renvoi.

. (2008). Hukum Notaris Indonesia, Tafsir Tematik Terhadap UU No. 30 Tahun 2004 tentang Jabatan Notaris, Bandung: Rafika Aditama.

Tan Thong Kie. (2007). Studi Notariat E Serba Serbi Praktek Notaris. Jakarta: PT Ichtiar Baru van Hoeve. 